\title{
Minimum Wage Impact on RMG Sector of Bangladesh: Prospects, Opportunities and Challenges of New Payout Structure
}

\author{
Ashik-Uz-Zaman*, Md Abdul Mannan Khan \\ Department of Accounting \& Information Systems, Bangabandhu Sheikh Mujibur Rahman Science \& Technology University, Gopalganj, \\ Bangladesh
}

Email Address:

ashik18162@gamil.com (Ashik-Uz-Zaman), mannan.cu@gmail.com (Md A. M. Khan)

${ }^{*}$ Corresponding author

\section{To cite this article:}

Ashik-Uz-Zaman, Md Abdul Mannan Khan. Minimum Wage Impact on RMG Sector of Bangladesh: Prospects, Opportunities and Challenges of New Payout Structure. International Journal of Business and Economics Research. Vol. 10, No. 1, 2021, pp. 8-20. doi: $10.11648 /$ j.ijber.20211001.12

Received: November 24, 2020; Accepted: December 17, 2020; Published: January 12, 2021

\begin{abstract}
Strike and labor unrest is very much common for the Readymade Garments (RMG) sector of Bangladesh. Most of them are basically for payment related issue like irregular wage payment practice of the garment factories owners and significant lag time of wage payment to the workers. With a view to maintaining stability in RMG sector, Ministry of Labor and Employment published new wage structure specially for the RMG sector in November 2018. Though new payout structure has been approved the effective implementation has become a great challenge for the governmental or regulatory authority as more than 50 percent increment in the lower graded workforce gross payout generates expectation gap of the owners of the RMG factories regarding the passion and value generating activities of the lower graded or minimum payout holder working force. High turnover in lower graded labor force and lack of working dedication generates reluctance of the owners to implement new payout structure of RMG sectors. However early stage patience and passion for working in RMG sector may gift a better career growth for the new workforce. Results have also justified the affiliation of a number of factors that may get influenced for the implementation of new minimum wage payout in the RMG sector.
\end{abstract}

Keywords: RMG Sector, Minimum Wage Payout, Payout Structure, BGMEA

\section{Introduction}

Countries which are basically cheap labor oriented hold the readymade garments sector as the major contributor of the total export for those particular countries. Cheap labor price reduces the overall readymade garments products' cost which gives those countries a competitive advantage in the global market. Therefore, Bangladesh might be more favorable choice for the international buyers for having lower manufacturing cost uniquely backed by low domestic wage rate [40]. From the perspective of garment factories, it is demanded that the salary of workers should be low due to following reasons to survive in the global completion [31], as this sector is based on relocation of production which takes place from high wage region to low cost production region [16]. For the allurement of such competitive advantage the owners of the garments industries in those countries are very much negligent towards the working condition along with the living standard of their workers. They are actually exploiting our cheap labor like foreign countries. This is the way our businessmen behave towards human being [8]. Therefore, workers of garments industries remained as the lowest paid workers in the world [25]. As a consequence, almost every year, the workers of RMG in different industries have been creating violence in the form of procession, vandalizing and blockading the roads to hike their minimum wage, attendance bonus and to ensure other facilities [26]. Such situation hampers the productivity and spoil the image of this industry to the global buyers that adversely affects the overall export of those countries though payout and other incentive hold better scenario for the RMG factories established in the export processing zones (EPZ) of the country [16]. 
This paper considers the minimum payouts of garments industries in Bangladesh at different period of times from 1984-85 to $2019-20$ along with its related effects on the performance and profitability of the overall garments industries. $6^{\text {th }}$ payout structure has been published by the Ministry of Labor and Employment in November, 2018. The previous payout structure has lost its effectiveness as 5\% usual yearly increment is not very sufficient as inflation rate of Bangladesh is still above $5.50 \%$. Therefore, it has been justified that minimum wage needs be fixed on a rate that helps meeting up the basic necessity of the least wage earner [12]. Now, 8,000 Tk. is the minimum gross payout per month as per the new wage structure and it is $77 \%$ higher in comparison to the previous [7] though the RMG workers' association proposed it for 12,020 takas per worker. Unfortunately, the implementation of new wage structure policy has not been assured effectively. Still a lots of lower graded workers are receiving lower amount than the amount approved minimum by the government [15]. Situations get more complicated since any hike in RMG sector wage level, it results in increased rent and price of necessary commodities that creates a localized inflation which minimizes the ultimate benefit of increased wage [23]. The objective of this paper is to investigate the factors $s$ that are affiliated with minimum payouts and their patter of getting influenced by it. Current implementation scenario of new wage structure has been depicted in this paper and the perspectives of owners regarding the new wage structure and probable reasons that hinders effective implementation of new payout policy have been investigated in this paper.

The next session of this paper considers the literature review, the later session will discuss about the data collection and orientation method. Discussion regarding research design, and development of hypotheses have also been performed and relevant results are analyzed. The last session is going to critically analyze the implementation scenario of the current payout structure, owners' perspective of the RMG industries by analyzing the interview data and career prospect analysis of lower graded new workforce or root level fresher workers through a couple of case studies.

\section{Literature Review}

Previously a number of studies are performed on the impact of minimum wage or incremental payout structure over the garments industries of Bangladesh. The level of wages is the most significant source of dissatisfaction for workers this sector [14]. Lack of compliance along with high turnover and low productivity are the major concerning issues of current situation for garments industries. Inadequate wage, mandatory overtime and insufficient payment for overtime, lack of motivation, long working hours and night shift, absence of appreciation for their contribution, irregular increments and promotion, job insecurity and less scope for self-skill development are some basic reasons for the employee dissatisfaction which subsequently cause employee turnover [5]. Even timely payout of sufficient wage may play crucial role for well motivation and better productivity
[7]. Higher the satisfaction of the workers always generates positive attitude and responsibilities towards work and are less prone to employee turnover and vice versa [38]. Adequate compensation, regularity in promotion and performance recognition and evaluation impart positive impact on employee performance [19]. Therefore, wages should be set at that level which might have the ability to generate high motivation of employees that eventually affects their performance as well [28]. The impact of wage rate on employees' social life is also explored and suggestions are provided for financial and social well-being for workers as living cost of Bangladesh is much higher in comparison to minimum payout [41]. Financial solvency and social status are being found to influence directly on the employee performance in labor intensive manufacturing industry [22]. It has also been clarified by neoclassical theory that standard minimum wage law, along with an appropriate implementation process, may have a positive effect on society too [14].

Labor productivity in Bangladesh is lower in comparison to other Asian or neighboring countries but the minimum pay is also lower than the living cost. Though a number of studies based on different countries have shown inverse relation between workers' wage and labor productivity [17, 29]. Weak relation between wage and labor production has been found because of faster labor productivity growth in comparison to wage [45]. Some studies have also found labor productivity as a consequence of labor wage as a partial factor since production capacity increased with comparatively low and steady wage payout structure [34]. However, some studies have also shown labor wage holds a significant positive correlation with labor productivity $[12,27,30]$ since with the hike in labor cost through payout increments or training program incentives, more proficient and diligent workers may emerge to work with effectiveness and efficiency [10]. Profitability of the RMG sector of Bangladesh in mid-market sector is considerably higher though initially after the imposition of minimum wage it faced a particular downfall [32]. Majority of the garments workers are female along with a moderate portion of male workers and non-recipient of even minimum wage is one of the major reasons of labor unrest [11]. Therefore, garments workers face difficulties in maintaining balance between wage and cost [36]. Recently, Oxfam has urged Australian retailers to enhance the price of finished goods by one percent so that Bangladeshi and Vietnamese RMG workers can receive a decent wage [13]. Garments owners exploit the workers not only through low wage payment but also with poor working condition, medicals, safety, leaves and other facilities. But through the coordinated effort of World Bank and BGMEA the situation is getting better day by day [18]. Favorable working conditions, better wages, minimum working hours, incentives and respect for equality can change into better and more satisfied workers that results in low employee turnover [3]. However, workers are more fascinated in wage and other financial incentives rather than working conditions and safety issue [23]. While setting the $4^{\text {th }}$ payout structure the minimum wage board considered total ten factors as: Cost of 
goods produced, production cost, productivity, cost of living, living standard, inflation rate, business capacity, job pattern and associated risk, socioeconomic condition of the country and other issues where severe controversy existed regarding cost of living among different organizations [44].

Bangladesh minimum wage was less than half in comparison to its competing countries as per ILO 2013. Fire incidences and factory building collapses symphonized the poor working condition. But situation is changing gradually in recent times because of transformation of garments workers into a social and political force. The threat of losing business from international buyers is forcing both owners and government for taking some effective steps [4]. Semieconomic indicators have no influence on productivity where minimum wage plays a significant role in increasing productivity. But increase in minimum wage will result Bangladesh to lose competitiveness in global market. After recent increase in minimum wage Bangladesh is still enjoying a high level of growth due to continuous rising trend in productivity of RMG workers has buffered the effect of minimum wage rising [39]. Low and discriminating wages along with highly unfair distribution of profits, lack of compliance and closure of factory without prior notice for indefinite time are the main underlying factors of unrest in the RMG sector of Bangladesh. Wages should be prioritized top to evade unrest in the RMG factories, along with the implementation of labor rights [9].

Female workers are discriminated in terms of wage level and wages were fixed far below the minimum level. A survey in 1998 showed that 73 percent of female workers along with 15 percent of male workers did not even receive the minimum wage level at that particular time [1]. Recent study also supports such result as only $4 \%$ of the female respondents confessed to receive more than 7,000 takas monthly where the figure is $45 \%$ for male garments worker respondents [2]. Majority of women regardless of whether they are employed as unskilled helpers or skilled tailors rarely receive the minimum wage which is legally stipulated [43]. The garments sector worker's wage is mostly discriminated because of their skill, working hours, age and experience but there may be a few individual incidences of wage based discrimination [20]. In such scenario, trade union may play key role in diminishing the incidents of low wage employment formation which is needed to be maintained [6].

\section{Data Collection and Orientation}

In this paper, both the primary and secondary data have been collected and analyzed. Through secondary source data has been collected and used for fiscal years 1984-85 to 2019-20. Most of the collected data are from the website of BGMEA. Other data used in this paper are from gazette and other governmental and non-governmental institutional publications. Some of the data are also taken from the other published papers through proper acknowledgement. Some web portals are also used for further support of the collected data.

In case of primary source, among the top RMG manufacturing organizations of Bangladesh 20 interviewees who are the chairman of their organizations, have participated in the interview session and shared their perception regarding the implementation of current wage payout structure approved by the government. They have also provided indications of the existing problems regarding the implementation of approved new payout structure. A couple of case study scenarios have also been depicted here for the career prospect of the lower graded workforce of the RMG sector as a signature of financial assistance of the approved payout structure implementations.

\section{Research Design}

In this paper, for the purpose of investigation simple regression analysis have been performed where the minimum payout has been considered as the independent variable and the other variables have been considered as dependent variables. As simple regression analysis has been used here as an analysis tool, single variable or one to one impact measurement model has been applied here. Therefore, total five individual models and hypotheses have been developed. Minimum payout is considered here as the lowest graded that means $7^{\text {th }}$ graded workers wage payout. As per the wage payout structure announced by the Ministry of Labor and Employment of Bangladesh there are total seven division or grades of workers in any RMG industry. The categorizations are performed based on their responsibilities and working scope $[15,33]$. Criterions for categorization are as follows:

Table 1. Grading of the Workforce of the RMG Sector As Per Positions.

\begin{tabular}{ll}
\hline Grades & Scope \\
\hline Grade 1 & Pattern Master, Chief Quality Controller \\
Grade 2 & Mechanic, Electrician, Cutting Master \\
Grade 3 & Sample Machinist, Senior Machine Operator \\
Grade 4 & Sewing Machine Operator, Quality Inspector, Cutter, Packer, \\
Grade 5 & Junior Leader \\
Grade 6 & Operator of General Sewing/Button Machines \\
Grade 7 & Assistant Sewing Machine Operator, Assistant Dry Washing \\
\hline
\end{tabular}

Five dependent variables have been considered here to depict the impact on the garments industries for the increment in the minimum payout. The variables are - number of garments factories, number of factory workers, RMG export amount, percentage of RMGs contribution to total export and per employee export contribution. Here the relationship between the independent variable and each of the dependent variables have been analyzed along with their impact significance and other related issues and the affiliated factors behave when new pay out structure has got approved or implemented.

A one to one interview has been performed with the chairmen of the 20 RMG factories which are among the top ranked garments factories of the country to obtain the view of the perspectives of the owners regarding the newly approved wage payout ratios by the government specially for the RMG sectors. For any sort of policy, implementation is the most challenging part. So current scenario of implementation has 
also been analyzed in this paper using secondary data sourced form Centre for Policy Dialogue (CPD). Interviews also comprised of the indications regarding the probable reasons of the reluctance of the garments owners regarding the implementation of approved pay out structure and relevant minimum payout of wage. A couple of case study scenarios have also been discussed in this paper for the career prospect of the lower graded workforce of the RMG sector as a signature for passionate stable new workforce for whom RMG sector can be a great opportunity for managing better career growth through skill development and dedication.

\section{Hypotheses Development}

\subsection{Number of Garments Factories}

As garments industries are considered the wheel of the economy of Bangladesh, government has provided different incentives in different periods to appreciate this sector. The factories are usually very much profitable along with some adverse effects occurred in a number exceptional events. If we observe used data, it can be found that the number of garments factories is showing an incremental trend congenial to the minimum payout amount though a drastic decrease had appeared at the 2013-14 fiscal year. So to test the relationship between the number of garments factories and minimum payout the following hypothesis has been proposed-

H1: Ceteris paribus, positive relationship prevails between the number of garments factories and minimum payout.

\subsection{The Number of Factory Workers}

Garments industries are considered as one of the major source of employment in the perspective of Bangladesh economy. A vast amount of both skilled and unskilled people are provided employment opportunity by these factories though the amount of payment is very much lower in comparison to the factories of other countries. If we observe used data, it can be found that the number of workers is showing an incremental trend though in recent years the number is very much static which may be a consequence of earnings increment in other sectors along with improved working condition. But the forecasted data has shown the possibility of hike in the labor amount if it is possible to increase the minimum payout amount. So to examine the relationship between the number of garments workers and minimum payout the following hypothesis has been proposed-

$\mathrm{H} 2$ : Ceteris paribus, positive relationship prevails between the number of garments workers and minimum payout.

\subsection{The Amount of RMG Export}

Since the labor is very much cheap in Bangladesh, the garments products cost relatively lower in comparison to other countries. So the owners of the garments factories enjoy a competitive advantage in the international market. As a result, the RMG export amount is showing an upward trend continuously from the beginning of the implementation of the $1^{\text {st }}$ salary structure. Severe increment is observed in the fiscal year of 2010-11. Recently the GSP privilege for Bangladesh has been cancelled but the RMG export maintains its rising trend as like the incremental trend of minimal payout. So to evaluate the relationship between the amount of RMG exports and minimum payout the following hypothesis has been proposed-

H3: Ceteris paribus, positive relationship prevails between the amount of RMG exports and minimum payout.

\subsection{Percentage of RMGs Contribution to Total Export}

Ready Made Garments sector is the second primary contributor of the total export of Bangladesh and this sector is expected to be more flourished in the upcoming periods along with the incremental contribution to the overall export arena of Bangladesh economy. Though in recent times the number of garments factories has decreased as per the data of BGMEA, the existing garments factories are doing well to recover the deficiencies. One of the major drivers of the improvement for the efficiency of garments industries is the reduction in the amount of turnover of the skilled employees along with the instigation development among the semi or unskilled employees through the annexation in the minimal payout for them. So to assess the relationship between RMGs' contribution to total export and minimum payout the following hypothesis has been proposed-

H4: Ceteris paribus, positive relationship prevails between RMGs contribution to total export and minimum payout.

\subsection{Yearly Contribution of Per Employee to Total Export}

Both the amount of export and the number of employees are following an upward trend but if we consider data table we will find that in the last recent years the number of employees are very much constant though a number of factories got closed but the amount of export is continuously showing an incremental trend from the very beginning to till now. So it is quite clear that the per employee contribution to the export is also increasing which may be considered a valid reason for the increment in the payout of our garments worker to inspire them more for quality works. So to assess the relationship between yearly contribution of per employee to total export and minimum payout the following hypothesis has been proposed-

H5: Ceteris paribus, positive relationship prevails between yearly contribution of per employee to total export to total export and minimum payout.

\section{Result Interpretations}

Here for the hypothesis 1 simple linear regression equation is $\hat{Y}_{1}=a+b_{1} X$ where $\hat{Y}_{1}$ is considered as the factory number and $\mathrm{X}$ is considered as minimum payout. We can see from table 7 that the value of $\mathrm{R}$ is 0.586 that indicates that the independent variable is positively related with the dependent variable which means that minimum wage and numbers of factories are moderately positively related. R-square value 0.343 means that $34.3 \%$ changes of the dependent variable 
(factory number) are explained by the changes of the independent variables (minimum payout). So $65.7 \%$ change cannot be considered by this equation. Adjusted R-square is 0.322 , which means that changes in number of factories does not change mostly for with the change in minimum payout and the other factors are the key role player here.

Here from tables 8 and 9 we can find that a significant positive coefficient $(\beta=.702, \rho<.01)$ for factory number variable which means increase employment opportunity will increase with the increment performed in minimum payout.

Here for the hypothesis 2 simple linear regression equation is $\hat{Y}_{2}=a+b_{2} X$ where $\hat{Y}_{2}$ is considered as the number of factory workers and $\mathrm{X}$ is considered as minimum payout. We can see from table 10 that the value of $\mathrm{R}$ is 0.818 that indicates that the independent variable positively related with the dependent variable which means that minimum wage and numbers of factory workers are much more positively related. R-square value 0.669 means that $66.9 \%$ changes of the dependent variable (number of workers) are explained by the changes of the independent variables (minimum payout). So $30.1 \%$ change cannot be considered by this equation. Adjusted R-square is 0.658 , which means that changes in number of factory workers changes moderately with the change in minimum payout.

Here from tables 11 and 12 we can find that a significant positive coefficient $(\beta=.001, \rho<.01)$ for worker number variable which means that increment in the minimum payout will allure the workers to prioritize the working opportunity in making their choice in selecting job. But here the capacity of workers' job accommodation in the garments factories should also be considered with great influence.

For the hypothesis 3 simple linear regression equation is $\hat{\mathrm{Y}}_{3}=\mathrm{a}+\mathrm{b}_{3} \mathrm{X}$ where $\hat{\mathrm{Y}}_{3}$ is considered as the amount of RMG export and $\mathrm{X}$ is considered as minimum payout. We can see from table 13 that the value of $\mathrm{R}$ is 0.956 that indicates that the independent variable has a high positive relation with the dependent variable which means that minimum wage and amount of RMG export are very much positively related. Rsquare value 0.914 means that $91.4 \%$ changes of the dependent variable (amount of RMG export) are explained by the changes of the independent variables (minimum payout). So the fit is pretty much good. But $8.60 \%$ change cannot be considered by this equation. Adjusted R-square is 0.911, which means that changes in amount of RMG export changes significantly with the change in minimum payout.

Here from tables 14 and 15 we can find that a significant positive coefficient $(\beta=5.628, \rho<.01)$ for amount of RMG export variable which means upsurge in minimum payout will amplify the foreign buyers' satisfaction and which results in improved customer retention rate in the long run. It will also help to remove current bad-tag of the garments industries called Sweat Shop. New foreign buyers will involve in procurement activities with our garments factories without any moral impediment factories which will boost up our RMG export.

For the hypothesis 4 simple linear regression equation is $\hat{\mathrm{Y}}_{4}=$ $a+b_{4} X$ where $\hat{Y}_{4}$ is considered as the percentage of $R M G$ contribution to total export and $\mathrm{X}$ is considered as minimum payout. We can see from table 16 that the value of $R$ is 0.492 that indicates that the independent variable is positively related with the dependent variable which means that minimum wage and the percentage of RMG contribution to total export are moderately positively related. R-square value 0.242 means that $24.2 \%$ changes of the dependent variable (percentage of RMG contribution to total export) are explained by the changes of the independent variables (minimum payout). So $75.8 \%$ change cannot be considered by this equation. Adjusted R-square is 0.217 , which means that changes in the percentage of RMG contribution to total export does not change mostly for with the change in minimum payout.

Here from tables 17 and 18 we can find that a significant positive coefficient $(\beta=0.007, \rho<.01)$ for the percentage of RMG contribution to total export variable which means that if the export of other products increases with RMG products export remaining constant or increases lower than those it will cause the percentage of RMG contribution to total export fluctuate. In these circumstances increment in minimum payout is not very much influential on RMGs contribution growth to total export. Such case can be handled through a proper diversification of the RMG export products.

Here for the hypothesis 5 simple linear regression equation is $\hat{\mathrm{Y}}_{5}=\mathrm{a}+\mathrm{b}_{5} \mathrm{X}$ where $\hat{\mathrm{Y}}_{5}$ is considered as yearly per employee contribution to total export and $\mathrm{X}$ is considered as minimum payout. We can see from table 19 that the value of $\mathrm{R}$ is 0.926 that indicates that the independent variable has significant positive relation with the dependent variable which means that minimum wage and per employee contribution to total export are very much positively related. R-square value 0.857 means that $85.7 \%$ changes of the dependent variable (per employee contribution to total export) are explained by the changes of the independent variables (minimum payout). So the fit is very good. But $14.3 \%$ change cannot be considered by this equation. Adjusted Rsquare is 0.852 , which means that changes in per employee contribution to total export significantly change with the change in minimum payout.

Here from tables 20 and 21 we can find that a significant positive coefficient $(\beta=1.055, \rho<.01)$ for per employee contribution to total export variable which means professes that it is logical to increase the minimum or overall payout for garments workers as their contribution is showing an upward trend continuously. In very recent times the number of garments factories has reduced for a number of reasons but continuous upward trend in export and per employee export contribution are giving a concrete evidence of incremental working efficiency.

It is quite clear from the above discussion that for all the selected dependent variables here are being possessed with the influence of minimum wage hike which is considered as independent variable in the applied models. Relationship that prevails between the independent variable and the dependent variables is positive but the level or depth of relationship varies from variable to variable. 


\section{Current Wage Payout Structure of RMG Sector and Its Implementations Scenario}

From the beginning of the history of RMG sector in Bangladesh, the employees of this sector is suffering from lowest payout among the other industries. Though minimum payout has been increased 6 times from 1985-2020, the fruitfulness of it has been obsoleted by the inflation and price hike. Even till now the payout amount of this sector is very much lower in comparison to that of the other top RMG exporter countries like China, India, Vietnam, Turkey and so on [24]. Even the margin of difference is also very much high which can be clearly understood form the charts below:

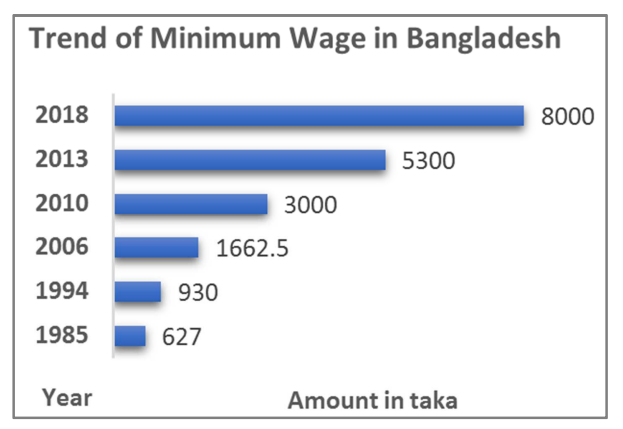

Figure 1. Minimum Wage Timeline of Bangladesh.

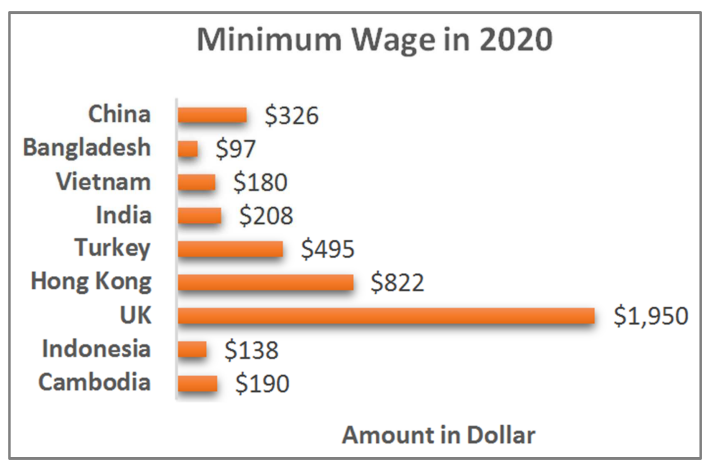

Figure 2. Minimum Wage of Top RMG Exporting Countries.

During financial year 2016-17 Bangladeshi government started to consider the necessity of a new pay out structure for the RMG sector with a view to perform an incremental reform regarding compensation received by the RMG sector workers in order to mitigate the labor unrest, hike in daily life expenses, irregular payout practice of the owners of the garments factories and so on. In response to the initiative taken by the government the workers associations and other RMG sector related parties provided a number of payout proposal for restructuring the payment structure of the RMG sector [37].

Table 2. Proposed payout structure by RMG Workers Association (Amount in taka).

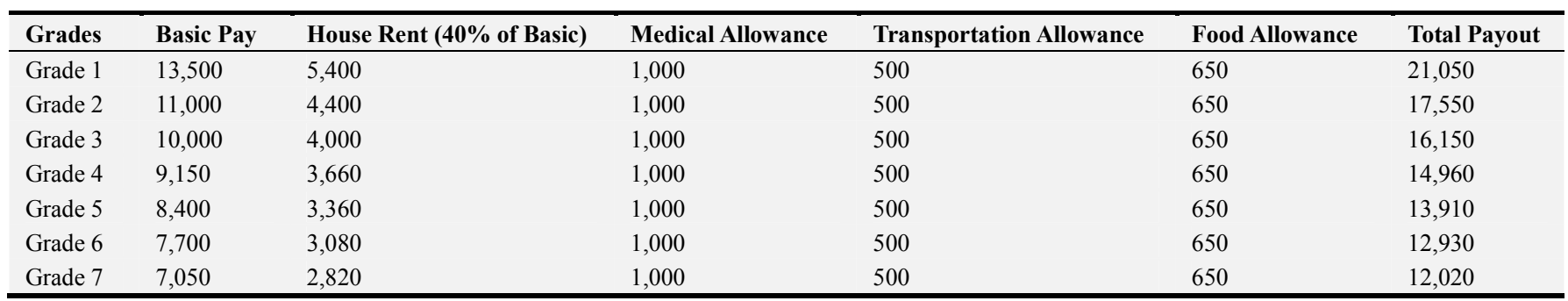

The relevant authoritative portion of the government had taken necessary time and thoroughly scrutinized the different proposals provided by the different stakeholders or parties related to the welfare of the workforce of the RMG sector, and then finally published the final new payout structure for the labor force of the garments sector. For almost all the payout amounts determined for existing seven graded labor force in the RMG sector could identified an incremental wave in their existing payout structure and in the new payout structure the basic and the gross payment both got upgradations and most significantly the minimum gross wage for the seventh or last grade shifted from 5,300 to 8,000 and the basic payout determined at 4,100 takas per month [33].

Table 3. Current payout structure of RMG sector (Amount in taka).

\begin{tabular}{|c|c|c|c|c|c|c|}
\hline Grades & Basic Pay & House Rent (50\% of Basic) & Medical Allowance & Transport Allowance & Food Allowance & Total Payout \\
\hline Grade 1 & 10,440 & 5,220 & 600 & 350 & 900 & 17,510 \\
\hline Grade 2 & 8,520 & 4,260 & 600 & 350 & 900 & 14,630 \\
\hline Grade 3 & 5,160 & 2,580 & 600 & 350 & 900 & 9,590 \\
\hline Grade 4 & 4,930 & 2,465 & 600 & 350 & 900 & 9,245 \\
\hline Grade 5 & 4,670 & 2,335 & 600 & 350 & 900 & 8,855 \\
\hline Grade 6 & 4,370 & 2,185 & 600 & 350 & 900 & 8,405 \\
\hline Grade 7 & 4,100 & 2,050 & 600 & 350 & 900 & 8,000 \\
\hline
\end{tabular}

Source: Ministry of Labour and Employment (2018-19) 
The current RMG Payout Structure 2018, designed by the governmental authority possesses different pattern in comparison to the previous two payout structure of the RMG sector that means 2010 or $4^{\text {th }}$ payout structure and 2013 or $5^{\text {th }}$ payout structure. New payout structure had become a demand of time because the $5 \%$ increment was not that much effective specially for the low income holder workers as the inflation rate of the country in recent decade never came down below 5.5\%. So, new wage structure appears to be blessings specially for downgraded workforce of RMG sector. Previous payout structures of the RMG sector were mostly comprised of basic payout which means the others allowances were no great contributor of the gross payout amount. But in the latest couple of versions of the RMG payout structure, comparatively lower increment in basic payout also sequestrates higher gross payout percentage growth as the other allowances have been enhanced or initiated. For example, the house rent allowance has been enhanced to 50 Percent from 40 percent in the latest payout structure in the RMG sector. Therefore, such allowance based payout structure put a synergic effect over gross payout though basic payout may not get that much incremental effect. In the current payout system only the house rent allowance is based on the basic payout but the all other payments are basically fixed in nature and regardless of the grade of the employee.

Table 4. Impact of Initiation of Allowance Based Payout Structure.

\begin{tabular}{|c|c|c|c|c|c|}
\hline \multirow{2}{*}{ Grades } & \multicolumn{3}{|c|}{ Basic as a percentage of Gross Wage } & \multirow{2}{*}{$\begin{array}{l}\text { Rise of basic from } 2013 \text { to } \\
2018\end{array}$} & \multirow{2}{*}{$\begin{array}{l}\text { Rise of gross from } 2013 \text { to } \\
2018\end{array}$} \\
\hline & 2010 & 2013 & 2018 & & \\
\hline Grade 1 & 69.9 & 65.4 & 59.6 & 22.8 & 34.7 \\
\hline Grade 2 & 69.4 & 64.2 & 58.2 & 21.7 & 34.2 \\
\hline Grade 3 & 68 & 59.9 & 53.8 & 26.6 & 40.9 \\
\hline Grade 4 & 67.7 & 59.2 & 53.3 & 29.7 & 44 \\
\hline Grade 5 & 67.4 & 58.4 & 52.7 & 32.3 & 46.6 \\
\hline Grade 6 & 67.1 & 57.6 & 52 & 33.6 & 48 \\
\hline Grade 7 & 66.7 & 56.6 & 51.3 & 36.7 & 50.9 \\
\hline
\end{tabular}

It is quite clear from the above table that the grade wise basic payouts are constituting lower of the gross payout with each upgradation of the payout structure. On the contrary gross payout is getting higher with the initiations of different allowances. Such behavior or impact can be severely felt by the lower graded workers as the fixed allowances are much higher in percentage as per their basic payout.

For any sort of policy making policy formulation or approval is considered as theoretical part where the policy implementation is considered as the practical or field work part.
Therefore, the main challenge is emerging now because only approval of a new payout structure will not solve the targeted problems. Implementations of such payout structure is the most crucial part of such policy effectiveness. Fixing and implementing the new wage structure have been the prime issue of recent labor unrest across the region [12]. To get the result authority must be alert to assure proper implementation of such policy imposed. Reluctance or the garments owners and lack of information or education of the workers regarding the new payout structure hinders the fruitfulness of such policies.

Table 5. Actual payout structure scenario of RMG sector (Amount in taka).

\begin{tabular}{lllllll}
\hline Grades & Basic Pay & House Rent (50\% of Basic) & Medical Allowance & Transport Allowance & Food Allowance & Total Payout \\
\hline Grade 1 & 10,848 & 4,339 & 250 & 200 & 650 & 16,287 \\
Grade 2 & 8,934 & 3,574 & 250 & 200 & 650 & 13,608 \\
Grade 3 & 5,201 & 2,080 & 250 & 200 & 650 & 8,381 \\
Grade 4 & 4,850 & 1,940 & 250 & 200 & 650 & 7,890 \\
Grade 5 & 4,505 & 1,802 & 250 & 200 & 650 & 7,407 \\
Grade 6 & 4,173 & 1,669 & 250 & 200 & 650 & 6,942 \\
Grade 7 & 3,829 & 1,532 & 250 & 200 & 650 & 6,461 \\
\hline
\end{tabular}

Source: Centre for Policy Dialogue (2019)

The above table clearly conveying the massage that even after the approval of the concerned governmental body, the RMG workers are yet getting deprived of their justified payout. The present minimum wage policy has not been implemented to its fullest as required to protect workers' due to inadequate mechanisms regarding implementation of minimum wage provisions under the Bangladesh labor legislation [42]. Though government selected a moderate payout policy buy considering the betterment of both the owners and the workers, the owners still lowering payout below the justified determined amount. Owners are able to manage such scope for exploitation because a lot of posts or position are not included in the gradation published in the gazette. Lack of guideline regarding the upgradation duration and competency determination have made the proper grading of the workers more complex [16]. Situation is worse for the lower graded workers as they are not so skilled, experienced and educated enough to have the information regarding the approval of new payout structure and bargain about their righteous justified payout amount [15]. 
Table 6. Scenario of Payout Deviation As Per Both Basic and Gross Wage (Amount in taka).

\begin{tabular}{|c|c|c|c|c|c|c|c|c|}
\hline \multirow{3}{*}{ Grades } & \multicolumn{4}{|c|}{ Basic Wage Payout Scenario } & \multicolumn{4}{|c|}{ Gross Wage Payout Scenario } \\
\hline & Actual Payout & Announced by Govt. & Gap & Percent & Actual Payout & Announced by Govt. & Gap & Percent \\
\hline & $A$ & $B$ & $A-B$ & $(A-B) / A$ & $C$ & $D$ & $C-D$ & $(C-D) / C$ \\
\hline Grade 1 & 16,287 & 17,510 & $-1,223$ & -7.51 & 10,848 & 10,440 & 408 & 3.76 \\
\hline Grade 2 & 13,608 & 14,630 & $-1,022$ & -7.51 & 8,934 & 8,520 & 414 & 4.63 \\
\hline Grade 3 & 8,381 & 9,590 & $-1,209$ & -14.42 & 5,201 & 5,160 & 41 & 0.79 \\
\hline Grade 4 & 7,890 & 9,245 & $-1,355$ & -17.17 & 4,850 & 4,930 & -80 & -1.65 \\
\hline Grade 5 & 7,407 & 8,855 & $-1,448$ & -19.55 & 4,505 & 4,670 & -165 & -3.66 \\
\hline Grade 6 & 6,942 & 8,405 & $-1,463$ & -21.07 & 4,173 & 4,370 & -197 & -4.72 \\
\hline Grade 7 & 6,461 & 8,000 & $-1,539$ & -23.83 & 3,829 & 4,100 & -271 & -7.08 \\
\hline
\end{tabular}

The data from the above table is clearly depicting that almost all graded employee are getting deprived of their justified or announced basic payout. The situation has got worse specially for the lower graded workers as their percentage of deviation is highly negative with the gradual degradation. Situation is comparatively better as per the gross payout scenario specially for the upper graded employees as the receive more payout then the amount approved by the government. But no matter whether it is gross or basic payout, the lower graded workers are getting themselves deprived in all the way, due to their lack of knowledge, beginning power and proper education.

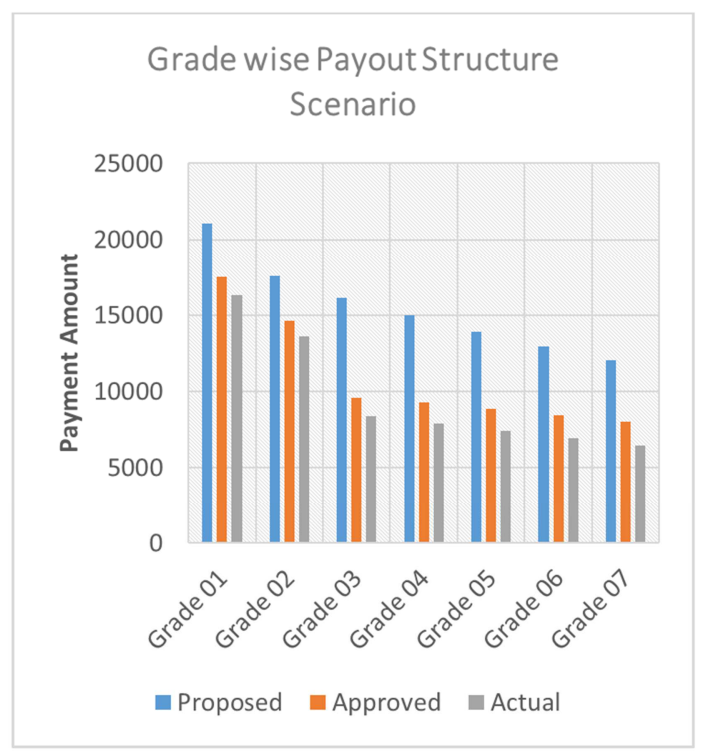

Figure 3. Payout Structure Scenario (Grade wise).

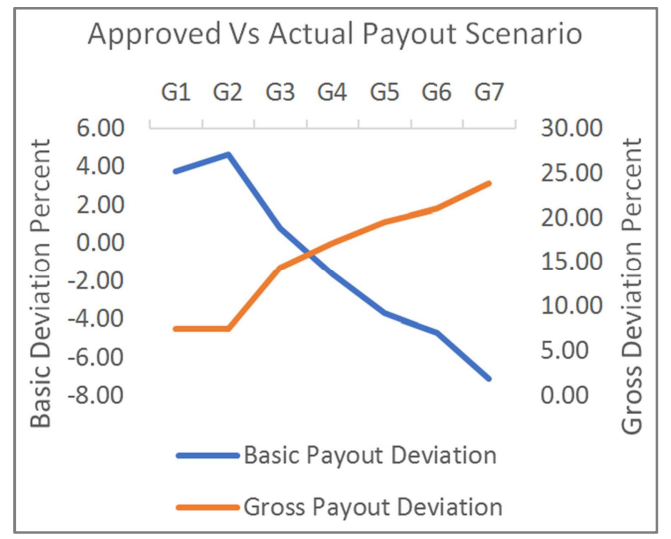

Figure 4. Approved Vs Actual Payout Scenario (Grade wise).
Graphical representation is conveying the massage regarding the overall summary of the prevailing scenario. Though RMG workers' association demanded a better payout for the lower graded workers too, the government responded in a better way for the upper graded workers. However, the minimum wage increased by a better margin for the lower graded workers, the reluctance of the RMG sector owners regarding proper implementation of wage payout structure refrains the policy to become more fruitful for each and every stage of workers. Though the new payout structure has assured a better situation for the upper graded workers, to make such policy working effectively for workers of each and every grades, the policy maker authority must be more focused on not only the approval of such payout policy but also on rigorous initiatives for the proper implementation of such policy as the lower graded workers are still away from the fruitfulness of new wage payout policy due to their lack of knowledge, skill and job security.

This paper has tried to find out the perceptions of the owners regarding the new or incremented new payout structure of the RMG sectors. Most of the interviewee has stated that they do not feel any problem regarding the implementation of new payout structure of the RMG sector but energy crunch, or low supply of gas and power, and workers with low or no skills hampers the production efficiency of the organizations which consecutively lowers the profit and enhances the lag time and damages reputations to the buyers and hinders the occurrence of repeated order placements and customer loyalty. Transcripts of some interviews with the chairmen of the top ranked cloth manufacturing organizations have been listed below:

"We, undoubtedly welcome the new payout structure of the RMG sectors as we also believe that it will act as an incentive for the skilled labor force to get involved and contribute toward the flourishment of the RMG sector of our country. But problem is the minimum wage holder worker that means the lower graded workers are usually non-skilled and their value addition contribution is also comparatively lower in comparison to the upper graded workers and trainee level contribution is usually performed by them with lower skills yet they are paid with minimum wage though trainee level payout is also available in new wage structure. Organizations expects some expertise from the labor force against the minimum wage but if the expectations are not met then problem with the payout may arise but on the contrary almost all the 
RMG organizations are eager enough to retain their skilled labor force even with the additional payment as per the current payout structure." (Chairman, Ha-Meem Group, 2019).

"Current payout structure of the RMG sector attracts both the skilled and unskilled labor force toward the garments industry. Problem arises when a worker without any prior experience enter into the workforce and perform very low or insignificant value generating activities. With the increment in the lower grades payout people who previously work in other sector or differently earned livelihood are rushed to get into RMG sector though a lot of among them have no passion or career plan to stay in working in RMG sector. They just rush temporarily and after some time when the gain some skills then the move to different organizations and sectors. New payout structure and passionate new workforce is always welcomed by us and we appreciate and motivate them with additional financial incentive who put sufficient value addition effort in the value chain of organization." (Chairman, Base Textile, 2019).

The owners of the RMG industries demands skillful workers against the new payout structure ratio of the RMG sectors and even they are eager to facilitate additional financial incentives for those with better contributions in the value chain of the organizations. Therefore, the main hindrance of proper implementation of current payout structure is the expectation gap of the owners regarding the value generating contribution of the lower graded workers. But scenario is not like that most of the new workforce of the RMG sector is les passionate and no career planning in RMG sector. A lot of young talented workforce got themselves involved in RMG sector and develop their life style than that of their former career. To see how that happens two case study have been included below:

Abdul, a 20 years old person came to Dhaka to earn his livelihood and financially assist his family in village as their financial conditions are not good at all. Initially he pulled rickshaw and after that he managed a job of a night guard. Due to zero career growth and job insecurity, Abdul was not satisfied with his current job. Abdul was looking for a job where career growth may be assured with efficiency and expertize is well appreciated. Then he joined in a RMG factory with the help of one of his friend who was already working in that factory. Though the income from this new job was a bit lower than his night guard job but he had not given up as he sensed a career growth opportunity. With absolute passion and eagerness, he upgraded his working grade in that RMG factory within a few years and now he works as a fourth graded worker in the organization and better able to support his family.

Sakhina, a 24 years old woman came to Dhaka from village with her husband. Because of early life marriage number children in her family is quite high. Her husband was a rickshaw puller. But income from only one earning member is not enough to make livelihood in Dhaka. Initially she worked as a home maid. But zero future prospect gave her mentally dissatisfaction though her income was not bad as the demand of home made in Dhaka is quite high. One day a neighbor heled her to manage a job in a RMG factory but the payment is equivalent to two third of what she got form her home maid occupation. But she sacrificed that for the mental satisfaction and her future development passion. She worked hard and that paid out. She now works as a fifth grade worker at her factory and now she earns far better than her previous occupation and she is happy what she has done since if she stayed in previous occupation the income of her may be static with zero growth. Now she and her husband both contribute in family income that provides better solvency.

If the new working force come up with passion and better career plan in the RMG sector, then hard work must pay back in the long run. However, at initial stage patience and planning are necessary to survive or stay in RMG sector. Though some deprivation in early stage may available in this sector but current payout policy must be a great assistance for those who are passionate in RMG sector and enters as a root level or lower graded worker as in their payout, influence of the new payout structure is very much significant. Therefore, RMG sector is always considered as a vast opportunity for better employment for any developing countries like Bangladesh.

\section{Conclusion}

The RMG sector is the most promising tool for export increment and economic development. It will be the invincible weapon for attaining the vision, mission and future primary goals of Bangladesh. A number of hazardous accidental events and worker strikes have made this sector instable than past years. Workers standard of living and working condition has become the major focus issue for the foreign buyers commercially related to our garments industries. Increase in minimum along with overall payout was a strong demand made both from workers and foreign stakeholders as it is one of the most important tools for improving the workers living standard.

From the evidence provided in this paper it is quite clear that increase in minimum payout is very much influential especially for attracting more efficient or semi-efficient workers in RMG sector which may upsurge the RMG export through the amplification of per employee contribution to total export. But for making a sustainable development in this sector, diversification in the RMG export products with proper quality is the urge of time. Value additive activities with the scope of innovation i.e. fashion designing should be focused more for creating new dimension in this sector [16].

This paper has shown that the minimum wage payout setting or increment has no significant influence as a determinant of RMG contribution to total export of country and number of garments factories. There are a number of other factors that have influence over them and act as their determinants. On the other hand, minimum wage payout has significantly act as one of the determinants of number of employs of the RMG sector as higher minimum wage attracts the new workforce toward the RMG sector [21, 35]. Higher minimum wage payout in lower graded labor will encourage the efficient workers not to 
leave the sector which may contribute positively toward the export form RMG sector and with the emergence of the efficient employee for higher minimum payout wage it will subsequently enhance the per employee contribution toward the export performance of the RMG sector of the country.

The owners of the RMG factories are reluctant to implement the approved new payout structure due to lack of expertise and higher employee turnover. They are reluctant to invest their time and money over the non-passionate unskilled workers. However, they are very much interested in appreciation of dedicated and well performing workforce as they have referred that the upper graded workforce is getting more than the approved payout structure as a part of additional financial incentives. The new workforce should be more patient and passionate in case of their job and future career in RMG sector. If they are able to pass the exam o patience in case of working as root level or lower graded workforce, then career growth may pay them back in the later time in a better way. Overall the owners of the RMG industries should also be more considerate toward the financial assistance and non-financial facilities of their workforce as they are the future asset of the RMG sector and with the assistance of their labor country will make its base stronger over the international markets of garments goods and boost up both the export of the country and the country's economy in the long run.

\section{Appendix: Result Output Tables}

Table 7. Model Summary for Hypothesis 1.

Model Summary

\begin{tabular}{lllll}
\hline Model & R & R Square & Adjusted R Square & Std. Error of the Estimate \\
\hline 1 & $.586^{\mathrm{a}}$ & .343 & .322 & 1391.19081 \\
\hline
\end{tabular}

a. Predictors: (Constant), Wage

Table 8. ANOVA Table - Hypothesis 1.

ANOVA ${ }^{a}$

\begin{tabular}{llllll}
\hline Model & & Sum of Squares & df & Mean Square & F \\
\hline \multirow{3}{*}{1} & Regression & 30368037.214 & 1 & 30368037.214 & 15.691 \\
& Residual & 58062356.255 & 30 & 1935411.875 & \\
& Total & 88430393.469 & 31 & & \\
\hline
\end{tabular}

a. Dependent Variable: Factory

b. Predictors: (Constant), Wage

Table 9. Coefficient Table of Hypothesis 1.

Coefficients $^{a}$

\begin{tabular}{|c|c|c|c|c|c|c|}
\hline \multicolumn{2}{|c|}{ Model } & \multicolumn{2}{|c|}{ Unstandardized Coefficients } & \multirow{2}{*}{$\begin{array}{l}\text { Standardized Coefficients } \\
\text { Beta }\end{array}$} & \multirow[t]{2}{*}{$\mathbf{t}$} & \multirow[t]{2}{*}{ Sig. } \\
\hline & & B & Std. Error & & & \\
\hline 1 & (Constant) & 1949.079 & 365.892 & & 5.327 & .000 \\
\hline
\end{tabular}

a. Dependent Variable: Factory

Table 10. Model Summary for Hypothesis 2.

Model Summary

\begin{tabular}{lllll}
\hline Model & R & R Square & Adjusted R Square & Std. Error of the Estimate \\
\hline 2 & $.818^{\mathrm{a}}$ & .669 & .658 & .78381 \\
\hline
\end{tabular}

a. Predictors: (Constant), Wage

Table 11. ANOVA Table - Hypothesis 2.

ANOVA ${ }^{a}$

\begin{tabular}{llllll}
\hline Model & & Sum of Squares & df & Mean Square & F \\
\hline \multirow{2}{*}{2} & Regression & 37.271 & 1 & 37.271 & 60.666 \\
& Residual & 18.431 & 30 & .614 \\
& Total & 55.702 & 31 & & \\
\hline
\end{tabular}

a. Dependent Variable: Workers

b. Predictors: (Constant), Wage 
Table 12. Coefficient Table of Hypothesis 2.

Coefficients $^{a}$

\begin{tabular}{lllllll}
\hline \multirow{2}{*}{ Model } & & \multicolumn{2}{l}{ Unstandardized Coefficients } & Standardized Coefficients & \multirow{2}{*}{ t } & \\
\cline { 3 - 7 } & & B & Std. Error & Beta & 3.369 & .002 \\
\multirow{2}{*}{2} & (Constant) & .695 & .206 & & .00 & .000 \\
\hline
\end{tabular}

a. Dependent Variable: Workers

Table 13. Model Summary for Hypothesis 3.

Model Summary

\begin{tabular}{lllll}
\hline Model & R & R Square & Adjusted R Square & Std. Error of the Estimate \\
\hline 3 & $.956^{\mathrm{a}}$ & .914 & .911 & 2469.30032 \\
\hline
\end{tabular}

a. Predictors: (Constant), Wage

Table 14. ANOVA Table - Hypothesis 3.

ANOVA ${ }^{a}$

\begin{tabular}{lllllll}
\hline Model & & Sum of Squares & df & Mean Square & F & Sig. \\
\hline \multirow{3}{*}{3} & Regression & 1952637669.205 & 1 & 1952637669.205 & 320.239 & $.000^{\mathrm{b}}$ \\
& Residual & 182923322.420 & 30 & 6097444.081 & & \\
& Total & 2135560991.625 & 31 & & & \\
\hline
\end{tabular}

a. Dependent Variable: Export

b. Predictors: (Constant), Wage

Table 15. Coefficient Table of Hypothesis 3.

Coefficients $^{a}$

\begin{tabular}{|c|c|c|c|c|c|c|}
\hline \multirow{2}{*}{ Model } & & \multicolumn{2}{|c|}{ Unstandardized Coefficients } & \multirow{2}{*}{$\begin{array}{l}\text { Standardized Coefficients } \\
\text { Beta } \\
\end{array}$} & \multirow{2}{*}{$\mathbf{t}$} & \multirow{2}{*}{ Sig. } \\
\hline & & B & Std. Error & & & \\
\hline & (Constant) & -1018.691 & 649.442 & & -1.569 & .127 \\
\hline 3 & Wage & 5.628 & .314 & .956 & 17.895 & .000 \\
\hline
\end{tabular}

a. Dependent Variable: Export

Table 16. Model Summary for Hypothesis 4.

Model Summary

\begin{tabular}{lllll}
\hline Model & R & R Square & Adjusted R Square & Std. Error of the Estimate \\
\hline 4 & $.492^{\mathrm{a}}$ & .242 & .217 & 17.74530 \\
\hline
\end{tabular}

a. Predictors: (Constant), Wage

Table 17. ANOVA Table - Hypothesis 4.

ANOVA $^{a}$

\begin{tabular}{lllllll}
\hline Model & & Sum of Squares & df & Mean Square & F & Sig. \\
\hline \multirow{3}{*}{4} & Regression & 3016.694 & 1 & 3016.694 & 9.580 & $.004^{\mathrm{b}}$ \\
& Residual & 9446.875 & 30 & 314.896 & & \\
& Total & 12463.569 & 31 & & & \\
\hline
\end{tabular}

a. Dependent Variable: Percentage

b. Predictors: (Constant), Wage

Table 18. Coefficient Table of Hypothesis 4.

Coefficients $^{a}$

\begin{tabular}{|c|c|c|c|c|c|c|}
\hline \multirow{2}{*}{ Model } & & \multicolumn{2}{|c|}{ Unstandardized Coefficients } & \multirow{2}{*}{$\begin{array}{l}\text { Standardized Coefficients } \\
\text { Beta }\end{array}$} & \multirow{2}{*}{$\mathbf{t}$} & \multirow{2}{*}{ Sig. } \\
\hline & & B & Std. Error & & & \\
\hline \multirow{2}{*}{4} & (Constant) & 53.500 & 4.667 & & 11.463 & .000 \\
\hline & Wage & .007 & .002 & .492 & 3.095 & .004 \\
\hline
\end{tabular}

a. Dependent Variable: Percentage 
Table 19. Model Summary for Hypothesis 5.

Model Summary

\begin{tabular}{lllll}
\hline Model & R & R Square & Adjusted R Square & Std. Error of the Estimate \\
\hline 5 & $.926^{\mathrm{a}}$ & .857 & .852 & 618.73894 \\
\hline
\end{tabular}

a. Predictors: (Constant), Wage

Table 20. ANOVA Table - Hypothesis 5.

ANOVA ${ }^{a}$

\begin{tabular}{llllll}
\hline Model & & Sum of Squares & df & Mean Square & F \\
\hline \multirow{3}{*}{5} & Regression & 68586381.357 & 1 & 68586381.357 & 179.153 \\
& Residual & 11485136.270 & 30 & 382837.876 & \\
& Total & 80071517.627 & 31 & & \\
\hline
\end{tabular}

a. Dependent Variable: Contribution

b. Predictors: (Constant), Wage

Table 21. Coefficient Table of Hypothesis 5.

Coefficients $^{a}$

\begin{tabular}{|c|c|c|c|c|c|c|}
\hline \multirow[t]{2}{*}{ Model } & & \multicolumn{2}{|c|}{ Unstandardized Coefficients } & \multirow{2}{*}{$\begin{array}{l}\text { Standardized Coefficients } \\
\text { Beta }\end{array}$} & \multirow[t]{2}{*}{$\mathbf{t}$} & \multirow[t]{2}{*}{ Sig. } \\
\hline & & B & Std. Error & & & \\
\hline 5 & $\begin{array}{l}\text { (Constant) } \\
\text { Wage }\end{array}$ & $\begin{array}{l}1387.181 \\
1.055\end{array}$ & $\begin{array}{l}162.732 \\
.079\end{array}$ & .926 & $\begin{array}{l}8.524 \\
13.385\end{array}$ & $\begin{array}{l}.000 \\
.000\end{array}$ \\
\hline
\end{tabular}

a. Dependent Variable: Contribution

\section{References}

[1] Absar, S. S., 2001. Problems surrounding wages: the readymade garments sector in Bangladesh. Labour and Management in Development Journal, Vol. 2, No. 7

[2] Afroz, N., Moloy, D.J. and Hossain, Z., 2018. SocioEconomic Status and Influencing Factors of Wage Discrepancy Among Ready-made Garment Workers in Bangladesh: Evidence from Dhaka City. Journal of Science and Technology, 8 (1 \& 2), pp. 21-30.

[3] Ahamed, F., 2013. Improving social compliance in Bangladesh's ready-made garment industry. Labour and Management in Development, 13.

[4] Ahmed, N. and Nathan, D., 2016. Improving wages and working conditions in the Bangladesh garment sector. Labour Conditions in Asian Value Chains, p. 51.

[5] Ahmed, S., Hasanuzzaman, M., Chowdhury, M. S. I., Shaikh, M.E. and Munir, M.S., 2018. A survey on the factors affecting employee turnover in the readymade garments of Bangladesh. Global Journal of Research in Engineering.

[6] Akterujjaman, S. M. and Ahmad, M. H., 2016. Workers' Satisfaction toward RMG Industry in Bangladesh: A Study on Dhaka and Gazipur City. International Journal of Research in Management \& Business Studies, 3 (2), pp. 22-30.

[7] Alam, M. N., Hassan, M. M., Bowyer, D. and Reaz, M., 2020. The Effects of Wages and Welfare Facilities on Employee Productivity: Mediating Role of Employee Work Motivation. Australasian Accounting, Business and Finance Journal, 14 (4), pp. 38-60.

[8] Azim, M. T. and Uddin, N., 2003. Challenges for garments sector in Bangladesh after 2004: Avenues for survival and growth. Bangladesh Institute of International and Strategic
Studies Journal, 24 (1), pp. 49-82.

[9] Bhuiyan, M. I., 2013. Reasonable Wages for Workers to Eliminate Unrest in Bangladesh's Readymade Garments (RMG) Sector. Fowler Street, USA: Bangladesh Development Research Center (BDRC).

[10] Bjuggren, C. M., 2018. Employment protection and labor productivity. Journal of Public Economics, 157, pp. 138-157.

[11] Chowdhury, M., Ahmed, R. and Yasmin, M., 2014. Prospects and Problems of RMG Industry: A study on Bangladesh. Prospects, 5 (7), pp. 103-118.

[12] Elahi, S., Hosen, M.D. and Nizam, M.E.H., 2019. Comparative analysis in RMG industries before and after Rana Plaza incident in Bangladesh. J Textile Eng Fashion Technol, 5 (4), pp.2 02-211.

[13] Emran, S. N., Kyriacou, J. and Rogan, S., 2019. Made in poverty the true price of fashion.

[14] Gaffar Khan, A., Ul Huq, S.M. and Islam, N., 2019. Job Satisfaction of Garments Industry in a Developing Country. Management Studies and Economic Systems, 4 (2), pp. 115122.

[15] Golam Moazzem, K., 2019. New Minimum Wage of the RMG Sector: Addressing the Issues of Non-Compliance in Implementation (No. 129). Centre for Policy Dialogue (CPD).

[16] Hasan, M. A., 2019. Minimum Wage in Readymade Garments Industry in Bangladesh. American Journal of Trade and Policy, 6 (2), pp. 57-66.

[17] Hermawan, I. and MSi, S. P., 2011. Analisis Dampak Kebijakan Makroekonomi Terhadap Perkembangan Industri Tekstil Dan Produk Tekstil Indonesia. Bulletin of Monetary Economics and Banking, 13 (4), pp. 1-28.

[18] Hoque, A. A., 2001. A Study of labor market condition on the Banladesh readymade garment industry (Doctoral dissertation, KDI School). 
[19] Huselid, M. A., 1995. The impact of human resource management practices on turnover, productivity, and corporate financial performance. Academy of management journal, 38 (3), pp. 635-672.

[20] Jamila, M., Talukdar, B. and Ahmed, S., 2006. Wage Discrimination in the Garments Sector of Bangladesh. Southeast University Journal of Business Studies, 2 (1).

[21] Kampelmann, S., Rycx, F., Saks, Y. and Tojerow, I., 2018. Does education raise productivity and wages equally? The moderating role of age and gender. IZA Journal of Labor Economics, 7 (1), p. 1.

[22] Khan, M. A., 2010. Effects of human resource management practices on organizational performance-an empirical study of oil and gas industry in Pakistan. European Journal of Economics, Finance and Administrative Sciences, 24 (157174), p. 6 .

[23] Khan, S., Bartram, T., Cavanagh, J., Hossain, M. and Akter, S., 2019. "Decent work" in the ready-made garment sector in Bangladesh: The role for ethical human resource management, trade unions and situated moral agency. Personnel Review, 48 (1), pp. 40-55.

[24] Khan, S. I. and Teicher, J., 2019. Are Overseas Sweatshops a Wicked Problem and Does it Matter? The Case of Readymade Garments Sector in Bangladesh. Wicked Solutions to Wicked Problems: The Challenges, ANZAM Conference.

[25] Khatun, R. and Shamsuzzaman, M., 2017. Job Satisfaction of RMG Sectors in Bangladesh: A Study on Female Workers of AKH Group. International Journal of Humanities \& Social Science Studies (IJHSSS), 3 (6), pp. 97-106.

[26] Khondhker Bazlul, Razzaque Abdur, and Ahmed Nazneen. "Exports, Employment and Working Conditions: Emerging Issues in the Post - MFARMG Industry."

[27] Kim, S. J. and Choi, S. O., 2018. The effects of job mismatch on pay, job satisfaction, and performance. Journal of Open Innovation: Technology, Market, and Complexity, 4 (4), p. 49.

[28] Klopotan, I., Mjeda, T. and Kurečić, P., 2018. Exploring the motivation of employees in a firm: A case-study. Business Systems Research Journal, 9 (1), pp. 151-160.

[29] Kohpaiboon, A., 2003. Foreign trade regimes and the FDIgrowth nexus: A case study of Thailand. The Journal of Development Studies, 40 (2), pp. 55-69.

[30] MAHARANI, T. and SETIAWAN, M., 2019. The Relationship Between Labor Wage and the Labor Productivity of the Indonesian Textile and Garment Industry.

[31] Majumder, P. P., 1998. Health status of the Garment workers in Bangladesh; Findings from a survey of employer and employees. Bangladesh Institute of Development Studies (BIDS), Dhaka, Bangladesh.

[32] Mansur, M., Kabir, M.R., Al Bashir, M.M. and Mustafa, M.S., The Impact of Revised Wage Rate on Firm's Competitiveness in the Ready Made Garment Sector of Bangladesh: A Case Study Comparison Between Large vs SME Garment Manufacturers.
[33] Ministry of Labor and Employment, (2019), Bangladesh Gazette, Additional Publication, S. R. O. No. 23/2019, Bangladesh Forms \& Publications

[34] Mottaleb, K.A. and Sonobe, T., 2011. An inquiry into the rapid growth of the garment industry in Bangladesh. Economic Development and Cultural Change, 60 (1), pp. 67-89.

[35] O'Connor, J., 2018. The impact of job satisfaction on the turnover intent of executive level central office administrators in Texas public school districts: A quantitative study of work related constructs. Education Sciences, 8 (2), p. 69.

[36] Osmani, N.M. and Hossen, B., 2018. Empowering Women in Bangladesh: A Study on the Problems of Working Women in Garments Industries. European Journal of Social Sciences, 57 (3), pp. 277-289.

[37] Piya, F. (2020). New Wage structure for RMG workers; Analysis and Possible Aftermath. Retrieved 17 February 2019, from http://textilefocus.com/new-wage-structure-rmgworkers-analysis-possible-aftermath/.

[38] Pushpakumari, M. D., 2008, January. The impact of job satisfaction on job performance: An empirical analysis. In City Forum (Vol. 9, No. 1, pp. 89-105).

[39] Rahman, K. and Paul, T. K., 2015. The Impact of Setting a Minimum Wage on RMG Sector: A Dynamic Panel Analysis. Available at SSRN 2827312.

[40] Rahman, K. M. and Chowdhury, E. H., 2020. Growth Trajectory and Developmental Impact of Ready-Made Garments Industry in Bangladesh. In Bangladesh's Economic and Social Progress (pp. 267-297). Palgrave Macmillan, Singapore.

[41] Salam, M. A. and McLean, G. N., 2014. Minimum wage in Bangladesh's ready-made garment sector: Impact of imbalanced rates on employee and organization development. HRD: Reflecting upon the Past Shaping the Future. Edinburgh Scotland: UFHRD http://www.ufhrd.co.uk/wordpress/wpcontent/uploads/2014/11/Abdus-Salam. pdf.

[42] Syed, R. F., 2020. Theoretical debate on minimum wage policy: a review landscape of garment manufacturing industry in Bangladesh. Asian Journal of Business Ethics, 9 (2), pp. 211-224.

[43] Uddin, G. S., 2008. Wage productivity and wage income differential in labor market: evidence from RMG sector in Bangladesh. Asian Social Science, 4 (12), pp. 92-101.

[44] Yunus, M. and Yamagata, T., 2012. The garment industry in Bangladesh. Dynamics of the Garment Industry in LowIncome Countries: Experience of Asia and Africa (Interim Report). Chousakenkyu Houkokusho, IDE-JETRO, 6, p. 29.

[45] Zhang, J. and Liu, X., 2013. The evolving pattern of the wage-labor productivity nexus in China: Evidence from manufacturing firm-level data. Economic Systems, 37 (3), pp. 354-368. 